\title{
Seed germination requirements of Hypericum scruglii, an endangered medicinal plant species of Sardinia (Italy)
}

\author{
Marco Porceddu, Martina Sanna, Sara Serra, Maria Manconi, and Gianluigi Bacchetta
}

\begin{abstract}
Hypericum scruglii Bacch., Brullo \& Salmeri is an endangered endemic plant of Sardinia, and the phloroglucinol compounds identified in this species have been reported to inhibit the activity of the Human Immunodeficiency Virus. Seed banks are a genetic repository that effectively preserve taxa of conservation interest, and they hold knowledge about the biology and germination ecophysiology of the taxa they preserve. The main goals of this study were to investigate the germination requirements for $\mathrm{H}$. scruglii, to evaluate the seed viability after eight years of long-term conservation and to suggest an efficient protocol for germination. Seeds stored at $-25{ }^{\circ} \mathrm{C}$ in the seed bank were tested at temperatures from 5 to $30^{\circ} \mathrm{C}$ and $25 / 10^{\circ} \mathrm{C}$. Base temperature $\left(T_{\mathrm{b}}\right)$ and thermal time $\left(\theta_{50}\right)$ for germination were estimated. Seeds of $\mathrm{H}$. scruglii germinated over a wide range of temperatures, responding positively to high temperatures and $25 / 10^{\circ} \mathrm{C}$. $\mathrm{T}_{\mathrm{b}}$ was estimated at $4.92{ }^{\circ} \mathrm{C}$, and $\theta_{50}$ was estimated at 198.27 degree days. The high viability detected in seeds of $\mathrm{H}$. scruglii allows us to suggest the use of seeds stored in a seed bank when fresh material for plant propagation is scarce. Our results provide new and useful baseline information for implementing conservation and multiplication strategies for this endangered medicinal plant.
\end{abstract}

Key words: endangered species, Hypericaceae, medicinal plant, plant propagation, seed banking.

Résumé : Hypericum scruglii Bacch., Brullo \& Salmeri est une plante endémique menacée de Sardaigne et on rapporte que les phloroglucinols identifiés chez cette espèce inhibent l'activité du virus d'immunodéficience humaine. Les banques de semences sont des dépôts génétiques qui permettent de préserver efficacement des taxons d'intérêt pour la conservation et elles abritent les connaissances sur la biologie et l'écophysiologie de la germination des taxons qu'elles préservent. Les objectifs principaux de cette étude consistaient à examiner les exigences de germination de $\mathrm{H}$. scruglii, à évaluer la viabilité des semences après huit ans de conservation à long terme et à suggérer des protocoles efficaces de germination. Les semences entreposées à $-25^{\circ} \mathrm{C}$ dans la banque ont été testées à des températures allant de 5 à $30^{\circ} \mathrm{C}$ et à $25 / 10^{\circ} \mathrm{C}$. La température de base $\left(\mathrm{T}_{\mathrm{b}}\right)$ et le temps thermique $\left(\theta_{50}\right)$ de germination ont été estimés. Les semences de $\mathrm{H}$. scruglii germaient à des températures étendues, répondant positivement à des températures élevées et à $25 / 10{ }^{\circ} \mathrm{C}$. La $T_{\mathrm{b}}$ a été estimée à $4,92{ }^{\circ} \mathrm{C}$, et le $\theta_{50}$ a été estimé à 198,27 degrés-jours. La viabilité élevée détectée chez les semences de $H$. scruglii permet aux auteurs de suggérer l'utilisation de semences entreposées dans les banques lorsque du matériel frais pour la propagation des plantes est rare. Ces résultats fournissent de l'information de base nouvelle et utile pour mettre en œuvre des stratégies de conservation et de multiplication pour cette plante médicinale menacée. [Traduit par la Rédaction]

Mots-clés : espèce menacée, Hypericaceae, plante médicinale, propagation de la plante, banque de semences.

\section{Introduction}

A medicinal plant is any plant containing substances that can be used for the synthesis of useful drugs (World Health Organization; WHO 2001). It is well known that some species belonging to the genus Hypericum (Hypericaceae) have medicinal proprieties. For example, H. perforatum L. is widely used in Europe as a drug for the treatment of mild to moderate depression (Brolis et al. 1998; Fiebich et al. 2011). Accumulating scientific evidence, together with the various traditional uses of Hypericum species, suggests plants of this genus have potential to treat diseases other than depression (Stojanovic et al. 2013; Mandrone et al. 2017). More recently, an important discovery was made regarding H. scruglii Bacch., Brullo \& Salmeri;

Received 26 February 2020. Accepted 18 May 2020.

M. Porceddu and G. Bacchetta. Sardinian Germplasm Bank (BG-SAR), Hortus Botanicus Karalitanus (HBK), University of Cagliari, Viale S. Ignazio da Laconi, 9-11, Cagliari 09123, Italy; Centre for the Conservation of Biodiversity (CCB), Life and Environmental Sciences Department, University of Cagliari, Viale S. Ignazio da Laconi 11-13, 09123 Cagliari, Italy.

M. Sanna and S. Serra. Centre for the Conservation of Biodiversity (CCB), Life and Environmental Sciences Department, University of Cagliari, Viale S. Ignazio da Laconi 11-13, 09123 Cagliari, Italy.

M. Manconi. Drug Science Division, Life and Environmental Sciences Department, University of Cagliari, 09124 Cagliari, Italy.

Corresponding author: Marco Porceddu (email: porceddu.marco@unica.it).

Copyright remains with the author(s) or their institution(s). Permission for reuse (free in most cases) can be obtained from copyright.com. 


\section{Pagination not final (cite DOI) / Pagination provisoire (citer le DOI)}

Sanna et al. (2018) identified phloroglucinol compounds in this plant that can inhibit the activities of the Human Immunodeficiency Virus type 1 (HIV-1). The results obtained by Sanna et al. (2018) emphasize the importance of extending research into this plant, so the development of an effective protocol for the conservation and multiplication of $\mathrm{H}$. scruglii is needed to reconcile the conservation interest of the species with research in the pharmaceutical field. In fact, in addition to its medicinal value, $H$. scruglii is an endemic plant species of Sardinia (Italy), and is categorized as Endangered in Global and Regional IUCN (International Union for Conservation of Nature) Red Lists (Bacchetta et al. 2010; Fois et al. 2014); however, absurdly, it is still not protected by local or international regulations. Given the growing importance of H. scruglii, the Sardinian Germplasm Bank (BG-SAR - University of Cagliari) ensures the conservation of this taxon, as well as other important plants, preserving them for the long-term (Porceddu et al. 2017c).

Ex situ conservation acts as a back-up for certain fields of plant diversity (Li and Pritchard 2009) and it is complementary to in situ conservation actions. The complementarity of ex situ and in situ conservation better safeguards endangered species (Fenu et al. 2020). However, the integration of the ex situ approach in an in situ program is still only adopted sporadically (Fenu et al. 2020). Thus, the ex situ conservation strategies are often the only way for the preservation of some endangered species (Maunder et al. 2004; Cochrane et al. 2007). Seed banking, as an integral part of the ex situ conservation, has a pivotal role in safeguarding plant species for long periods of time and in developing standard viability monitoring protocols (Bewley and Black 1994). In addition to their role in ex situ conservation, seed banks are also a source of knowledge about the germination ecophysiology of the taxa they hold, by determining germination and multiplication protocols for many of these species (Bewley and Black 1994; Valderrábano et al. 2018).

To understand the reproductive mechanisms of $H$. scruglii and to suggest an efficient protocol for seed germination and multiplication, study of its germination ecophysiology under a wide range of temperature is fundamental. Temperature is one of the most important environmental conditions that control germination (Garcia-Huidobro et al. 1982; Probert 2000). The germination response in relation to accumulated temperature has been modelled using a thermal time $(\theta)$ approach (Covell et al. 1986; Pritchard and Manger 1990), and allows for the description of linear change in germination rate under different conditions and for the estimation of thresholds for the germination response (Porceddu et al. 2017b; Seal et al. 2018; Fernández-Pascual et al. 2019). As reported by Mattana et al. (2019) in their study on the critically endangered wild medicinal plant Dioscorea strydomiana Wilkin, limited data are available with regard to thermal thresholds for seed germination of wild native species.

In this study, we investigated the seed germination ability of H. scruglii. Specifically, the aims of the work were (i) to identify the temperature requirements for germination of $\mathrm{H}$. scruglii and to evaluate the viability of its seeds by determining the germination capacity after eight years of long-term conservation, (ii) to detect the base temperature $\left(T_{b}\right)$ and the thermal requirements $(\theta)$ for seed germination, and (iii) to suggest a germination protocol for this taxon. This knowledge is important because $H$. scruglii was recently recognized as a plant of high pharmaceutical value, and in the future, there may be a need to propagate the species by seeds. This approach may be an example for other important medicinal plant species that require rapid conservation efforts to prevent and (or) mitigate the extinction risk. The new data presented in this work would guarantee greater protection of the species in nature, also taking into account that it is considered to be in danger of extinction.

\section{Materials and methods}

Study species

Hypericum scruglii is a vascular plant species distributed through central and south east Sardinia, in particular the Sarcidano, Barbagia of Seulo, Ogliastra, and Quirra regions (Bacchetta et al. 2010). The species is generally associated with calcareous substrates such as limestone, conglomerate, travertine, sandstone, and marl, where it grows exclusively on damp soil near springs or streams with freshwater (Bacchetta et al. 2010). It is a perennial herb 5-30 cm tall, herbaceous, prostrate to decumbent. Flowering occurs in late June or July and fruiting in August and September. The fruit consists of an ellipsoid capsule, tridentate with loculi longly apiculate, which contains numerous small brownish seeds, $0.7-0.9 \mathrm{~mm}$ long, with testa finely reticulate-scalariform (Bacchetta et al. 2010). The seeds of $H$. scruglii have been reported to exhibit orthodox storage behaviour (Royal Botanic Gardens, Kew 2020).

\section{Seed collection and treatment}

Collection of H. scruglii seeds was carried out in September 2011, in a locality of Laconi (Oristano province, Sardinia, Italy) named Santa Sofia. A sample of the collected seeds was transferred, as a "safety duplication", to the Millennium Seed Bank of the Royal Botanic Gardens, Kew, in accordance with the terms and conditions of the Memorandum of Collaboration between BG-SAR and Kew. Germination rates of $96 \%$ at $20{ }^{\circ} \mathrm{C}$ (seeds sown: 47) and of $100 \%$ at alternating temperatures $25 / 10{ }^{\circ} \mathrm{C}$ (seeds sown: 42 ), both with a light/dark regime of $8 / 16 \mathrm{~h}$, were recorded in fresh seeds tested before long-term conservation in the seed bank (Royal Botanic Gardens, Kew 2020). Following international standards for long term storage (Bacchetta et al. 2006, 2008), the seeds were gradually dried at $15{ }^{\circ} \mathrm{C}$ and $15 \%$ relative humidity (RH), to 
Fig. 1. (A) Final germination percentages and (B) germination rate of Hypericum scruglii at each tested temperature (5, 10, 15, 20, $25,30^{\circ} \mathrm{C}$ and $25 / 10^{\circ} \mathrm{C}$ ). The points correspond to the mean of four replicates. Continuous lines show fitted Weibull functions, calculated using germination parameters. Dashed lines indicate the time to achieve the $T_{50}$. Different letters in (B) indicate significant differences $(P<0.05)$ of $T_{50}$ by post hoc pairwise $t$ test comparisons.

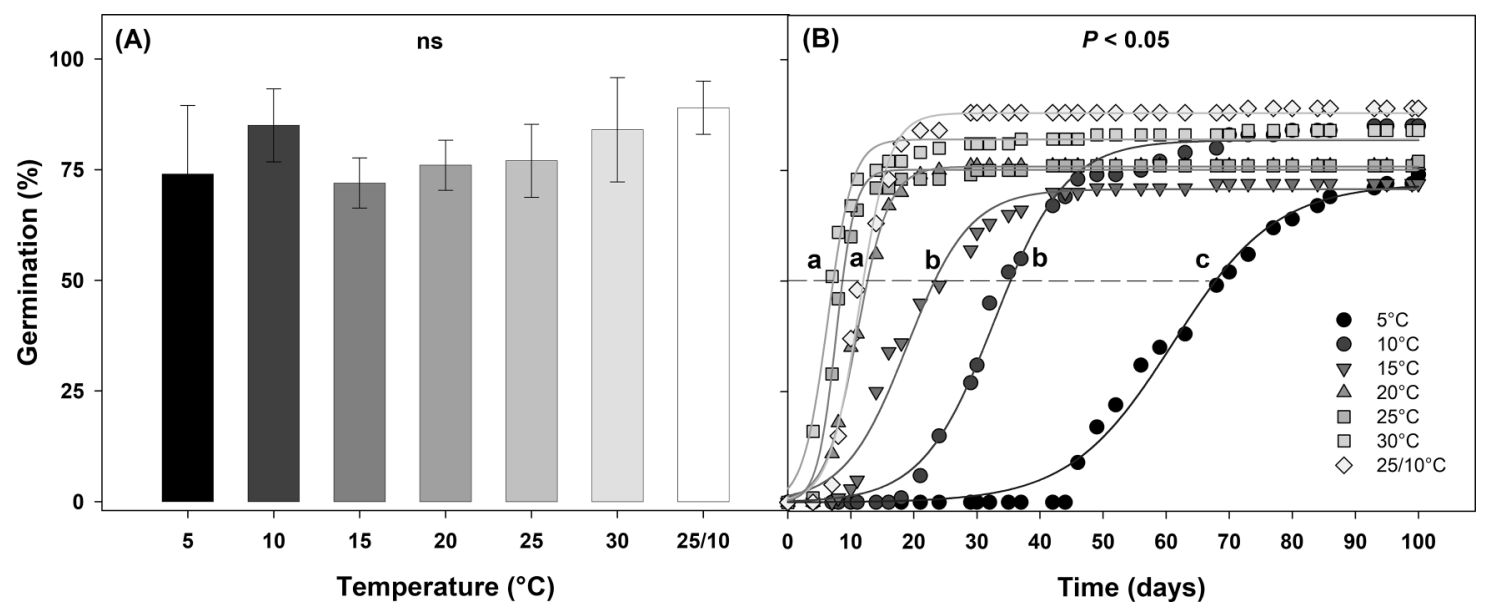

reach ca. $3 \%-5 \%$ internal seed moisture content, and then were stored at $-25{ }^{\circ} \mathrm{C}$ at BG-SAR (Porceddu et al. $2017 c$ ). Before the germination tests the stored seeds were removed from storage and brought to room temperature (ca. $20^{\circ} \mathrm{C}$ and $40 \% \mathrm{RH}$ ) for $12 \mathrm{~h}$, to restore internal seed humidity.

\section{Seed germination experiments}

Four replicate samples of 25 seeds each were sown on the surface of 1\% agar water, in plastic Petri dishes (60 $\mathrm{mm}$ in diameter). They were incubated at a range of constant temperatures $\left(5,10,15,20,25\right.$, and $\left.30{ }^{\circ} \mathrm{C}\right)$ and one alternating temperature $\left(25 / 10^{\circ} \mathrm{C}\right)$, with $12 \mathrm{~h}$ of irradiance per day in germination chambers (Sanyo MLR-351) equipped with white fluorescent lamps (FL40SS.W/37 70$\left.10 \mu \mathrm{mol} \cdot \mathrm{m}^{-2} \cdot \mathrm{s}^{-1}\right)$. In the alternating temperature regime, the $12 \mathrm{~h}$ light period coincided with the period of elevated temperature. All of the germination tests were conducted in 2018. Germination of the seeds, defined as visible radicle emergence with length $>1 \mathrm{~mm}$, was scored three times a week.

\section{Thermal time base temperature}

Thermal time analysis was carried out for $\mathrm{H}$. scruglii seeds germinating at constant temperatures from 5 to $30{ }^{\circ} \mathrm{C}$. Estimates of time ( $t$, days) taken for cumulative germination to reach different percentiles $(g)$ for successive increments of $10 \%$ germination were interpolated from the germination progress curves (Covell et al. 1986). Germination rate $\left(1 / t_{g}\right)$ was regressed, using a linear model, as a function of temperature according to the following equation:

$$
1 / t_{g}\left(\text { days }^{-1}\right)=\left(T_{g}-T_{b}\right) / \theta
$$

where $T_{b}$ corresponds to the base temperature for germination and $\theta$ to the thermal time (Garcia-Huidobro et al. 1982 ). The mean ( \pm 1 SD) of the $x$-intercept among percen- tiles was calculated for the suboptimal temperature range $\left(5-30^{\circ} \mathrm{C}\right)$ to establish $\mathrm{T}_{\mathrm{b}}$ (Pritchard and Manger 1990). Thermal time $\left(\theta ;{ }^{\circ} \mathrm{Cd}\right.$, degree days) estimates were then calculated separately as the inverse of the suboptimal regression equations (Covell et al. 1986).

\section{Data and statistical analysis}

The final germination percentages were calculated as the mean of the four replicates $( \pm S D)$ based on the total number of filled seeds. Furthermore, the germination rate $\left(T_{50}\right)$ was defined as the time (in days) required to reach $50 \%$ germination success.

Generalized linear models (GLMs) were used to evaluate the effects of incubation temperature on final seed germination percentage and on the $T_{50}$. A logit link function and quasibinomial error structure was used to analyse seed germination percentages, whereas a log link function and Poisson error structure was used for analysing $T_{50}$. In the subsequent ANOVA, F tests with an empirical scale parameter were used instead of chi-square (Crawley 2007). Significant differences highlighted by the GLM were then analysed using post-hoc pairwise comparisons $t$ test (with Bonferroni adjustment). All statistical analyses were carried out with $R$ version 3.0.3 (R Core Team 2015).

\section{Results}

\section{Seed germination}

Seeds of $\mathrm{H}$. scruglii stored for eight years at $-25{ }^{\circ} \mathrm{C}$ were able to germinate under a wide range of constant temperature regimes and at the alternating temperature tested (Fig. 1A). High germination percentages $(>70 \%)$ were observed at all tested temperatures (Fig. 1A). There was no statistically significant $(P>0.05)$ effect on final germination percentages (dependent variable) for temperature (Table 1). However, there was a statistically significant effect $(P<0.001)$ on the germination rate 
Table 1. GLM results for the dependent variables seed germination (\%) and germination rate $\left(T_{50}\right)$ for the Temperature factor $\left(5,10,15,20,25,30^{\circ} \mathrm{C}\right.$ and $\left.25 / 10{ }^{\circ} \mathrm{C}\right)$.

\begin{tabular}{lcccccc}
\hline Germination & df & Deviance & Resid.df & Resid.dev. & $F$ & $P$ \\
\hline$\%$ Null & & & & & & \\
$\quad$ Temperature & 6 & 62.996 & 21 & 204.56 & & \\
$T_{50}$ & & & 27 & 423.56 & 1.8853 & 0.1309 \\
$\quad$ Null & & & & & \\
$\quad$ Temperature & 6 & 414.07 & 21 & 9.01 & & $<2.2^{\mathrm{e}-16}$ \\
\hline
\end{tabular}

(calculated on the $T_{50}$ values) for temperature (Table 1 ). The post-hoc pairwise $t$ tests highlighted no statistical difference $(P>0.05)$ among the temperatures 20, 25, and $30{ }^{\circ} \mathrm{C}$ as well as $25 / 10^{\circ} \mathrm{C}$ (here identifiable as "Group with letters a") and between 10 and $15{ }^{\circ} \mathrm{C}$ (here identifiable as "Group with letters b") (Fig. 1B). However, the $T_{50}$ obtained at $5{ }^{\circ} \mathrm{C}$ was statistically different $(P<0.05)$ with respect to "Group with letters a" (i.e., 20, 25, $30{ }^{\circ} \mathrm{C}$ and $25 / 10{ }^{\circ} \mathrm{C}$ ) and to "Group with letters b" (i.e., 10 and $15^{\circ} \mathrm{C}$ ) (Fig. 1B). In general, seeds tested at temperatures above $5{ }^{\circ} \mathrm{C}$ needed ca. 30 days to reach $T_{50}$, whereas at $5{ }^{\circ} \mathrm{C}$ the value was reached in ca. 70 days. The higher temperatures (seeds of "Group with letters a") accelerated germination, reducing the time to reach $T_{50}$ to ca. 10 days (Fig. 1B). In addition to the germination results, we observed that the first stages of seedling development of $H$. scruglii under controlled conditions (at $20{ }^{\circ} \mathrm{C}$ and in a sterilized soil substrate) did not manifest any evident problems (Fig. 2).

\section{Base temperature and thermal time}

Based on germination rate responses for each 10th percentile from $10 \%$ to $70 \%$ germination, it was possible to estimate the mean base temperature $\left(T_{b}\right)$ for germination (Fig. 3A). Average $T_{b}$ value for $H$. scruglii was $4.92 \pm 1.13{ }^{\circ} \mathrm{C}$ (Fig. 3A). Figure 3B shows the relationship between thermal time $\left(\theta_{\mathrm{g}}\right)$ and germination percentage. According to the linear regression equation obtained $(y=0.29 x-8.92)$, the thermal time required for $50 \%$ germination $\left(\theta_{50}\right)$ was estimated at $198.27^{\circ} \mathrm{Cd}$ (Fig. 3B).

\section{Discussion}

Our results show that the seeds of $H$. scruglii germinated under controlled conditions and they responded positively to both constant and alternating temperatures. Indeed, high germination percentages $(>70 \%)$ were recorded under all of the conditions tested. As noted during the experiment, when considering the rate of germination, the species responds to treatments with high temperatures (from 20 to $30{ }^{\circ} \mathrm{C}$ ) and alternating temperature $\left(25 / 10{ }^{\circ} \mathrm{C}\right)$, reaching the $T_{50}$ values within 10 days. There are relatively few complete studies on the germination biology and thermal requirements of Hypericum species. Pérez-García et al. (2006) found that germination temperatures had no significant effect on final germination percentages in $H$. perforatum, and that the germination process ends within 30 days. Con-
Fig. 2. Germinated seed (A), seedlings with cotyledons (B), and developed seedlings (C) of Hypericum scruglii propagated at the BG-SAR under controlled conditions. [Colour online.]

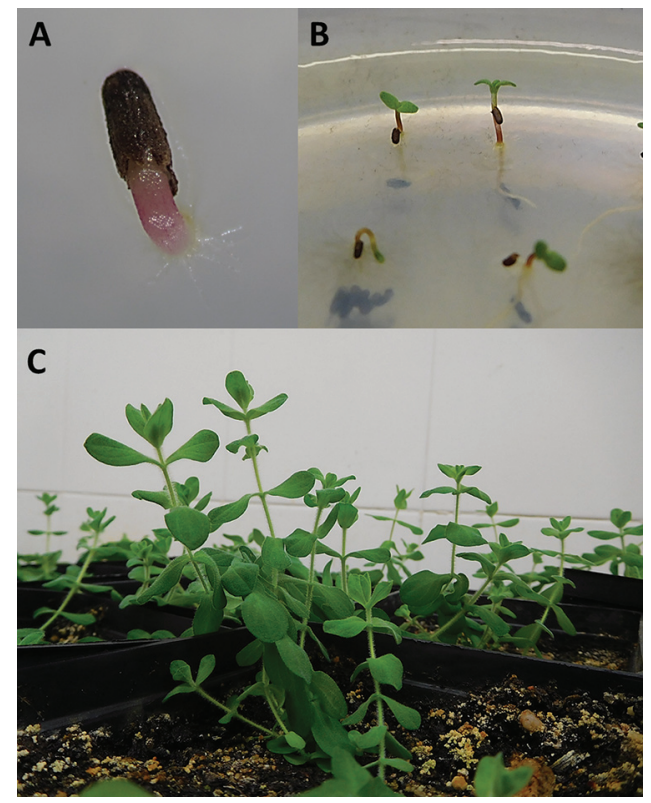

versely, seeds of other Hypericum species need specific treatments (e.g., cold or warm stratification, gibberellins) and (or) conditions (e.g., light, dark) to promote and ensure germination (Sánchez-Coronado et al. 2015; Carta et al. 2016; Rosbakh et al. 2020). Our study provides important new data for the germination requirements of $H$. scruglii, increasing knowledge regarding the germination biology of members of the genus Hypericum.

The results of our study demonstrate that the preservation methods and ex situ strategies implemented by the seed bank were effective forms of long-term storage (Porceddu and Bacchetta 2018). The outcome of this work may have positive implications for the preservation and conservation of $\mathrm{H}$. scruglii, as it is evident that seeds stored at $-25{ }^{\circ} \mathrm{C}$ for eight years have maintained their viability and a high germination capacity. This behaviour is in accordance with that detected in other Hypericum species; for example, seeds from species belonging to the same genus have been reported to maintain their viability for at least 7-13 years of long term storage (see Table 2).

The identification of a suitable range of incubation temperatures allowed us to estimate the minimum ger- 
Fig. 3. (A) Base temperatures $\left(T_{\mathrm{b}}\right)$, calculated for different germination percentiles of Hypericum scruglii seeds incubated at each suboptimal constant temperature $\left(5,10,15,20,25\right.$, and $\left.30^{\circ} \mathrm{C}\right)$. Linear regressions of percentiles where values for $P>0.05$ were not included. (B) Thermal times $\left(\theta_{\mathrm{g}}\right.$, expressed in $\left.{ }^{\circ} \mathrm{Cd}\right)$ calculated from germination time-courses from estimated $\mathrm{T}_{\mathrm{b}}$ of $4.92{ }^{\circ} \mathrm{C}$. Thermal times to reach $\theta_{50}$ are shown with a dashed line.
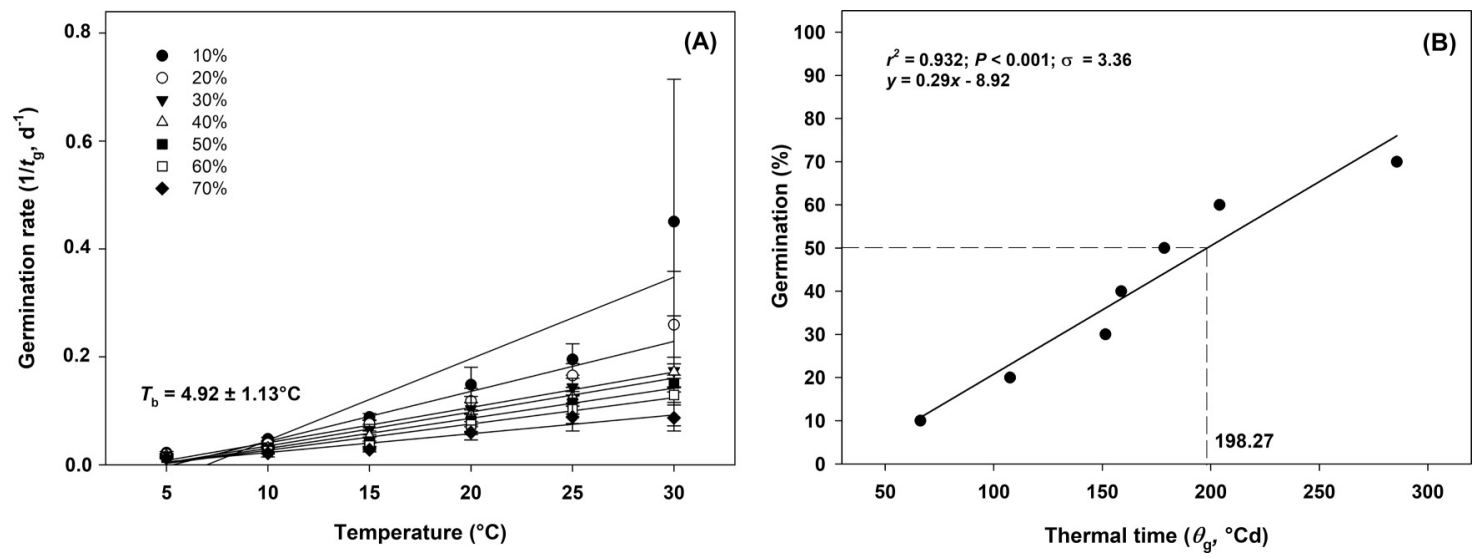

Table 2. Examples and related information for Hypericum species that maintain their viability for at least seven years of long-term storage.

\begin{tabular}{llll}
\hline Species & $\begin{array}{l}\text { Years of } \\
\text { storage }\end{array}$ & $\begin{array}{l}\text { Average change in } \\
\text { germination (\%) }\end{array}$ & Source \\
\hline H. reflexum L.f. & 13 & 100 to 97 & Royal Botanic Gardens, Kew (2020) \\
H. androsaemum L. & 11 & 100 to 98 & Royal Botanic Gardens, Kew (2020) \\
H. perforatum L. & 11 & 100 to 92 & Royal Botanic Gardens, Kew (2020) \\
H. tomentosum L. & 8 & - & Montezuma-De-Carvalho et al. (1987) \\
H. canadense L. & 7 & 82 to 80 & Walsh et al. (2003) \\
& & 90 to 72 & \\
H. hirsutum L. & 7 & 81 to 72 & Walsh et al. (2003) \\
\hline
\end{tabular}

mination temperature and thermal requirements of H. scruglii. The base temperature for germination $\left(T_{b}\right)$ of H. scruglii was estimated at $4.92^{\circ} \mathrm{C}$, and the thermal time to reach $\theta_{50}$ was estimated at $198.27^{\circ} \mathrm{Cd}$ (degree days). To our knowledge, to date, no information is available in the literature on the base temperature and thermal time of Hypericum species, so this work is the first attempt at reporting thermal threshold data for seed germination in the genus. However, the $T_{b}$ and $\theta_{50}$ values estimated in this work for $\mathrm{H}$. scruglii are consistent with the thermal thresholds reported for seed germination of Mediterranean species, in which base temperature ranges from -9 to $9{ }^{\circ} \mathrm{C}$ and thermal time from 22 to $357^{\circ} \mathrm{Cd}$ (Picciau et al. 2019).

In light of the recently discovered medicinal potential of phloroglucinol compounds in H. scruglii to inhibit the activities of HIV-1 (Sanna et al. 2018), one of the main goals of this study was to suggest a germination protocol for this taxon, in the assumption that an efficient protocol for seed germination must be taken into account to ensure the availability of plants cultivated ex situ (Porceddu et al. 2017a). In general, propagation from seed is relatively inexpensive and usually effective, but often the particularities of germination requirements are unknown or only partially known (e.g., Cuena-Lombraña et al. 2016; Picciau et al. 2017). On the basis of our results, we suggest that the efficient protocol for seed germination of $\mathrm{H}$. scruglii consists of seed incubation at $20-30{ }^{\circ} \mathrm{C}$, or alternating temperature of $25 / 10{ }^{\circ} \mathrm{C}$, under a photoperiod of $12 \mathrm{~h}$ light/12 $\mathrm{h}$ dark. A seed germination protocol facilitates propagation of the species at any time, guaranteeing the availability of the plants for multiple purposes, such as natural population reinforcement, phytopharmaceutical research, chemical and pharmacological studies. In addition, the propagation of plants in ex situ environments may bypass the natural phenological timing of the species, ensuring that the plant material is available when it is needed.

The high viability detected in seeds of $H$. scruglii stored for eight years under seed banking conditions, and the efficient protocol for seed germination for this species proposed in this work, allows us to suggest the use of stored seeds when fresh material for plant propagation is scarce or is not available (Godefroid et al. 2016). Especially in the case of endemic and threatened species, which may present problems related to the poor availability of material for plant propagation, seed banks can be important sources of plant materials (Godefroid et al. 2016; Cuena-Lombraña et al. 2020). The availability of plant materials in ex situ germplasm banks could effectively contribute to the reduction of the plant-harvest pressure on wild populations, moving the attention of 
the collectors from plants to seeds. However, it is important to remember that germplasm collection, conservation and movement may be subject to international and national regulations, and this operation must be carried out by authorized and trained persons (Valderrábano et al. 2018).

\section{Conclusions}

This study demonstrates that seeds of $\mathrm{H}$. scruglii can achieve high germination percentages under laboratory conditions, even after at least eight years of long-term storage in a seed bank. The high viability detected in seeds of $\mathrm{H}$. scruglii allows us to suggest the use of seeds stored in seed bank when fresh material for plant propagation is scarce or is not available. These results provide new and useful baseline information for implementing conservation and multiplication strategies for this endangered medicinal plant.

\section{References}

Bacchetta, G., Fenu, G., Mattana, E., Piotto, B., and Virevaire, M. 2006. Manuale per la raccolta, studio, conservazione e gestione ex situ del germoplasma. Manuali e Linee guida APAT, Roma, Italia.

Bacchetta, G., Bueno Sánchez, A., Fenu, G., Jiménez-Alfaro, B., Mattana, E., Piotto, B., and Virevaire, M. 2008. Conservación ex situ de plantas silvestres. Principado de Asturias / La Caixa.

Bacchetta, G., Brullo, S., and Salmeri, C. 2010. Hypericum scruglii sp. nov. (Guttiferae) from Sardinia. Nord. J. Bot. 28: 469-474. doi:10.1111/j.1756-1051.2009.00736.x.

Bewley, J.D., and Black, M. 1994. Seeds: physiology of development and germination. 2nd ed. Plenum Press, New York.

Brolis, M., Gabetta, B., Fuzzati, N., Pace, R., Panzeri, F., and Peterlongo, F. 1998. Identification by high-performance liquid chromatography-diode array detection-mass spectrometry and quantification by high-performance liquid chromatography-UV absorbance detection of active constituents of Hypericum perforatum. J. Chromatogr. A, 825: 9-16. doi:10.1016/ S0021-9673(98)00697-9.

Carta, A., Probert, R., Puglia, G., Peruzzi, L., and Bedini, G. 2016. Local climate explains degree of seed dormancy in Hypericum elodes L. (Hypericaceae). Plant Biol. 18: 76-82. doi:10.1111/plb. 12310. PMID:25662792.

Cochrane, J.A., Crawford, A.D., and Monks, L.T. 2007. The significance of ex situ seed conservation to reintroduction of threatened plants. Aust. J. Bot. 55: 356-361. doi:10.1071/ BT06173.

Covell, S., Ellis, R.H., Roberts, E.H., and Summerfield, R.J. 1986. The influence of temperature on seed germination rate in grain legumes. I. A comparison of chickpea, lentil, soyabean and cowpea at constant temperatures. J. Exp. Bot. 37: 705715. doi:10.1093/jxb/37.5.705.

Crawley, M.J. 2007. The R book. John Wiley and Sons Ltd., Chichester, UK.

Cuena-Lombraña, A., Porceddu, M., Dettori, C.A., and Bacchetta, G. 2016. Gentiana lutea L. subsp. lutea seed germination: natural versus controlled conditions. Botany, 94(8): 653-659. doi:10.1139/cjb-2016-0030.

Cuena-Lombraña, A., Sanna, M., Porceddu, M., and Bacchetta, G. 2020. Does storage under gene bank conditions affect seed germination and seedling growth? The case of Senecio morisii (Asteraceae), a vascular plant exclusive to Sardinian water meadows. Plants, 9(5): 581. doi:10.3390/plants9050581.

Fenu, G., Bacchetta, G., Christodoulou, C.S., Cogoni, D.,
Fournaraki, C., Gian Pietro, G.G., et al. 2020. A common approach to the conservation of threatened island vascular plants: first results in the Mediterranean Basin. Diversity, 12(4): 157. doi:10.3390/d12040157.

Fernández-Pascual, E., Mattana, E., and Pritchard, H.W. 2019. Seeds of future past: climate change and the thermal memory of plant reproductive traits. Biol. Rev. Camb. Philos. Soc. 94(2): 439-456. doi:10.1111/brv.12461. PMID:30188004.

Fiebich, B.L., Knorle, R., Appel, K., Kammler, T., and Weiss, G. 2011. Pharmacological studies in an herbal drug combination of St. John's Wort (Hypericum perforatum) and passion flower (Passiflora incarnata): in vitro and in vivo evidence of synergy between Hypericum and Passiflora in antidepressant pharmacological models. Fitoterapia, 82: 474-480. doi:10.1016/j.fitote. 2010.12.006. PMID:21185920.

Fois, M., Cuena-Lombraña, A., Fenu, G., and Bacchetta, G. 2014. Hypericum scruglii Bacch., Brullo et Salmeri. Schede per una Lista Rossa della Flora vascolare e crittogamica Italiana. Inf. Bot. Ital. 46(2): 285-321.

Garcia-Huidobro, J., Monteith, J.L., and Squire, G.R. 1982. Time, temperature and germination of pearl millet (Pennisetum typhoides S. and H.). J. Exp. Bot. 33: 288-296. doi:10.1093/jxb/ 33.2.288.

Godefroid, S., Le Pajolec, S., and Van Rossum, F. 2016. Pretranslocation considerations in rare plant reintroductions: implications for designing protocols. Plant Ecol. 217: 169182. doi:10.1007/s11258-015-0526-0.

Li, De-Z, and Pritchard, H.W. 2009. The science and economics of ex situ plant conservation. Trends Plant Sci. 14(11): 614621. doi:10.1016/j.tplants.2009.09.005. PMID:19818672.

Mandrone, M., Scognamiglio, M., Fiorentino, A., Sanna, C., Cornioli, L., Antognoni, F., et al. 2017. Phytochemical profile and $\alpha$-glucosidase inhibitory activity of Sardinian Hypericum scruglii and Hypericum hircinum. Fitoterapia, 120: 184-193. doi: 10.1016/j.fitote.2017.06.020. PMID:28647480.

Mattana, E., Gomez-Barreiro, P., Lötter, M., Hankey, A.J., Froneman, W., Mamatsharaga, A., et al. 2019. Morphological and functional seed traits of the wild medicinal plant Dioscorea strydomiana, the most threatened yam in the world. Plant Biol. 21(3): 515-522. doi:10.1111/plb.12887. PMID:30076674.

Maunder, M., Guerrant, E.O., Havens, K., and Dixon, K.W. 2004. Realizing the full potential of ex situ contributions to global plant conservation. In Ex situ plant conservation: supporting species survival in the wild. Edited by E.O. Guerrant, K. Havens, and M. Maunder. Island Press, Washington, D.C. pp. 389-418.

Montezuma-De-Carvalho, J., Paiva, J., and Pimenta, M.C.S. 1987. Effect of cold storage on seed viability of aromatic plants from the Portuguese flora. In The Eucarpia International Symposium on Conservation of Genetic Resources of Aromatic and Medicinal Plants, Estaçao Agronómica Nacional Oeiras. pp. 111-116.

Pérez-García, F., Huertas, M., Mora, E., Peña, B., Varela, F., and González-Benito, M.E. 2006. Hypericum perforatum L. Seed germination: interpopulation variation and effect of light, temperature, presowing treatments and seed desiccation. Genet. Resour. Crop Evol. 53(6): 1187-1198. doi:10.1007/s10722-0052012-3.

Picciau, R., Porceddu, M., and Bacchetta, G. 2017. Can alternating temperature, moist chilling, and gibberellin interchangeably promote the completion of germination in Clematis vitalba seeds? Botany, 95(8): 847-852. doi:10.1139/cjb2017-0039.

Picciau, R., Pritchard, H.W., Mattana, E., and Bacchetta, G. 2019. Thermal thresholds for seed germination in Mediterranean species are higher in mountain compared with lowland areas. Seed Sci. Res. 29(1): 44-54. doi:10.1017/S0960258518000399. 


\section{Pagination not final (cite DOI) / Pagination provisoire (citer le DOI)}

Porceddu, M., and Bacchetta, G. 2018. Ex situ conservation of Mediterranean vascular flora. In Conserving wild plants in the south and east Mediterranean region. Edited by M. Valderrábano, T. Gil, V. Heywood, and B. De Montmollin. IUCN, Gland and Málaga. pp. 115-118. Available from https://portals.iucn.org/library/sites/ library/files/documents/2018-048-en.pdf [accessed 21 February 2020].

Porceddu, M., Fenu, G., and Bacchetta, G. 2017a. New findings on seed ecology of Ribes sardoum: can it provide a new opportunity to prevent the extinction of a threatened plant species? Syst. Biodivers. 15(5): 480-488. doi:10.1080/14772000. 2016.1271058.

Porceddu, M., Mattana, E., Pritchard, H.W., and Bacchetta, G. 2017b. Dissecting seed dormancy and germination in Aquilegia barbaricina, through thermal kinetics of embryo growth. Plant Biol. 19(6): 983-993. doi:10.1111/plb.12610. PMID:28762612.

Porceddu, M., Santo, A., Orrù, M., Meloni, F., Ucchesu, M., Picciau, R., et al. 2017c. Seed conservation actions for the preservation of plant diversity: the case of the Sardinian Germplasm Bank (BG-SAR). Plant Sociol. 54(2): 111-117. doi:10. 7338/pls2017542S1/11.

Pritchard, H.W., and Manger, K.R. 1990. Quantal response of fruit and seed germination rate in Quercus robur L. and Castanea sativa Mill., to constant temperatures and photon dose. J. Exp. Bot. 41: 1549-1557. doi:10.1093/jxb/41.12.1549.

Probert, R.J. 2000. The role of temperature in germination ecophysiology. In Seeds - the ecology of regeneration in plant communities. Edited by M. Fenner. CAB International, Wallingford, UK. pp. 261-292.

$\mathrm{R}$ Core Team. 2015. R: a language and environment for statistical computing. R Foundation for Statistical Computing, Vienna, Austria. Available from http://www.R-project.org.

Rosbakh, S., Baskin, C.C., and Baskin, J.M. 2020. Nikolaeva et al.'s reference book on seed dormancy and germination.
[Supporting Information.] Ecology. [Online ahead of print.] doi:10.1002/ecy.3049.

Royal Botanic Gardens, Kew. 2020. Seed Information Database (SID). Version 7.1. Available from http://data.kew.org/sid/ [accessed 20 September 2018, 02 April 2020].

Sánchez-Coronado, M.E., Olvera, C., Márquez-Guzmán, J., Macías-Rubalcava, M.L., Orozco, S., Anaya, A.L., and Orozco-Segovia, A. 2015. Complex dormancy in the seeds of Hypericum philonotis. Flora, 213: 32-39. doi:10.1016/j.flora.2015. 04.001.

Sanna, C., Scognamiglio, M., Fiorentino, A., Corona, A., Graziani, V., Caredda, A., et al. 2018. Prenylated phloroglucinols from Hypericum scruglii, an endemic species of Sardinia (Italy), as new dual HIV-1 inhibitors effective on HIV-1 replication. PLoS ONE, 13(3): e0195168. doi:10.1371/journal.pone. 0195168. PMID:29601601.

Seal, C.E., Barwell, L.J., Flowers, T.J., Wade, E.M., and Pritchard, H.W. 2018. Seed germination niche of the halophyte Suaeda maritima to combined salinity and temperature is characterised by a halothermal time model. Environ. Exp. Bot. 155: 177-184. doi:10.1016/j.envexpbot.2018.06.035.

Stojanovic, G., Dordevic, A., and Smelcerovic, A. 2013. Do other Hypericum species have medical potential as St. John's wort (Hypericum perforatum)? Curr. Med. Chem. 20: 2273-2295. doi: 10.2174/0929867311320180001. PMID:23521674.

Valderrábano, M., Gil, T., Heywood, V., and de Montmollin, B. 2018. Conserving wild plants in the south and east Mediterranean region. IUCN, Gland, Switzerland and Málaga, Spain. doi:10.2305/IUCN.CH.2018.21.en.

Walsh, D.G.F., Waldren, S., and Martin, J.R. 2003. Monitoring seed viability of fifteen species after storage in the Irish Threatened Plant Genebank. Biol. Environ. 103B: 59-67. doi: 10.3318/BIOE.2003.103.2.59.

WHO. 2001. Geneva legal status of traditional medicine and complementary/alternative medicine: a worldwide review. World Health Organisation, Geneva. pp. 129-143. 